\title{
Linkage Analysis of Hereditary Spherocytosis in Four Generations of a Family with SPTB Gene Deficiency
}

\author{
Pelin TASDEMIR ${ }^{1}$, S. Sennur DEMIREL ${ }^{2}$ \\ ${ }^{1}$ Selcuk University Meram Faculty of Medicine, Blood Center \\ ${ }^{2}$ Selcuk University Meram Faculty of Medicine, Department of Medical Biology, Konya, TURKEY
}

\begin{abstract}
Hereditary Spherocytosis (HS) is an inherited hemolytic anemia caused by the defects on membrane proteins and characterized by icterus, anemia and splenomegaly. Hereditary Spherocytosis clinically and genetically comprises a heterogeneous group of hemolytic anemias. In about $75 \%$ of the cases, the inheritance follows an autosomal dominant pattern and about $25 \%$ of cases occur sporadically. The aim of this study was to find which gene was responsible for the autosomal dominant HS in a large family of four generations. The linkage to the major HS genes (including SPTA1, SPTB, ANK1 ve SLC4A1) was searched by using LINKAGE and MERLIN analysis and LOD-score statistical calculations. As a result of using these analyses, we confirmed that the HS in this family was an autosomal dominant form of the disease and the incidence was linked to the SPTB gene which maps to chromosome 14. Linkage analysis is an effective prescreening method in genetically heterogeneous diseases and a new mutation analysis study is in the planning stage to detect the mutation in the SPTB gene.
\end{abstract}

Keywords: Gene mapping, Hereditary spherocytosis, Linkage analysis, Spectrin

\section{ÖZET}

\section{SPTB Gen Defekti Olan Dört Kuşaklı Herediter Sferositozlu Bir Ailede Bağlantı Analizi}

Herediter sferositoz (HS), membran proteinlerinin defektleri nedeniyle oluşan; anemi, sarılık ve splenomegali ile karakterize herediter bir hastalıktır. HS, klinik ve genetik olarak hem dominant hem de resesif kalıımla ilişkili heterojen bir hastalıktır. Olguların \% 75'i otozomal dominanttır, \% 25 olguda ise bir aile hikayesi yoktur. Bu çalışmanın amacı dört kuşaklı geniş bir ailede rastlanan otozomal dominant geçişli Herediter sferositoz'da hangi gendeki mutasyonun patolojiden sorumlu olduğunu bulmaktır. Herediter sferositoz'da majör etkili olan SPTA1, SPTB, ANK1 ve SLC4A1 genlerine bağlantının varı̆̆l; bağlantı (LINKAGE) ve MERLIN analizi ayrıca LOD skor istatistiksel hesaplamaları kullanılarak araştııımıştır. Sonuç olarak; bu analizlerin kullanımı ile araştırdığımız ailede görülen Herediter Sferositoz'un otozomal dominant olarak kalıtılığı ve 14 numaralı kromozomda yerleşik olan SPTB geninin hastalıktan sorumlu olacağı bulunmuştur. Genetik heterojenite gözlenen hastalıklarda bağlantı analizi, etkin bir ön tarama yoludur ve bağlantı gözlenen SPTB geninde mutasyon taraması yapılabilmesi için yeni bir çalşma planlanacaktır.

Anahtar Kelimeler: Gen haritalaması, Herediter sferositozis, Bağlantı analizi, Spektrin 


\section{INTRODUCTION}

Hereditary Spherocytosis (HS) is a clinically and genetically heterogeneous disorder of the red blood cells (RBCs). ${ }^{1}$ The biochemical defects in HS are related to abnormalities in the RBC membrane proteins. ${ }^{2} \mathrm{HS}$ is characterized by a broad spectrum of clinical severity, ranging from asymptomatic form to life-threatening anemia with transfusion dependence. ${ }^{3}$

Approximately $75 \%$ of cases display an autosomal dominant pattern of inheritance but about $10-25 \%$ of the cases reveal no family story, comprising recessive forms and de novo mutations. ${ }^{4,5}$

This disorder, including the mild or subclinical forms, is the most common cause of inherited chronic hemolysis in Northern Europe and North America with a prevalence ranging from 1:2000 to $1: 5000{ }^{6,7}$ It has also been described in other populations, especially in Japan. ${ }^{8}$

In adults, the clinical signs of HS are hyperhemolysis, anemia, icterus and splenomegaly. HS is characterised by the presence of spherocytes (spherical-shaped erythrocytes) on the peripheral blood smear. Spherocytes are spheric shaped microcytic cells with no pale area in it. In HS, there is increased fragility of the red cell membrane, loss of membrane surface area, and trapping and destruction of the red cells in the spleen. ${ }^{10}$

The molecular defect is highly heterogeneous, involving the genes encoding for spectrin, ankyrin, band 3 and protein 4.2. ${ }^{11}$ Spectrin is the main component of the erythrocyte skeleton. This filamentous protein is composed of two subunits, $\alpha$ and $\beta$, that are encoded by separate genes SPTAl and SPTB. The $\alpha$ and $\beta$ chains intertwine in an antiparallel manner to form heterodimers which come together head to head to form tetramers. ${ }^{12}$ Spectrin tetramers are secured to the membrane by interaction of $\beta$-spectrin chains with ankyrin, a protein that forms a bridge to a major transmembrane protein, the anion exchanger known as band 3. This binding is strengthened by other protein interactions..$^{13,14}$

In early studies in 1985 biochemical analysis of the membrane skeleton proteins showed that spectrin is deficient in patients with HS..$^{15}$ It was mentioned that the amount of spectrin deficiency correlates with the severity of the disease and response to splenectomy. Cytogenetic and genetic linkage analyses later sho- wed that ankyrin defects are an underlying cause of HS in some families. ${ }^{16,17}$ Subsequent work showed that most patients with HS had combined spectrin and ankyrin deficiency ${ }^{18,19}$ In patients with HS, the biochemical analysis of the red cell membrane proteins by sodium dodecyl sulfatepolyacrylamide gel electrophoresis (SDS-PAGE) has identified four distinct abnormalities corresponding to four different subsets; (1) isolated deficiency of spectrin, (2) combined deficiency of spectrin and ankyrin, (3) deficiency of band-3 protein, (4) deficiency of protein 4.2..$^{20}$ Our current understanding is that HS is caused by defects in the proteins involved in the vertical interactions between the membrane skeleton and the lipid bilayer.

A lot of molecular defects have been determined in several HS patients by different authors. The genes responsible for developing HS are SPTA1, SPTB, $A N K 1$, SLC4A1 and EPB42. These are huge genes with many exons. For this reason linkage analysis is an effective method to recognize the candidate gene.

The subject of this study is a Turkish family composed of four generations and 19 affected members. Affected members of the family was examined and clinically diagnosed in pediatric hematology clinic of our hospital. We performed genotyping and linkage analysis based on the genomic positions of functional candidate genes to identify the locus for the gene that is mutated in HS. We revealed the linkage between HS and RBC membrane protein coding genes.

\section{MATERIALS AND METHODS}

A four generation Turkish family with autosomal dominant HS was studied. The family consisted of 86 members and 19 of them was affected. Splenectomy had been performed in all of the affected individuals. The proposita was a 14-year-old girl who was diagnosed in the pediatric hemotology clinic of Selcuk University Meram Medical Faculty Hospital in Konya. After the examination, splenomegaly, jaundice, hemolysis and increased osmotic fragility of the erythrocytes was determined. Other affected members of the family were sharing the characteristic features of the disease and had underwent splenectomy. The pedigree of the family is specified in the Figure 1. The study was approved by the Selcuk University Ethics Committee and written informed consent was taken from the members of the family. 


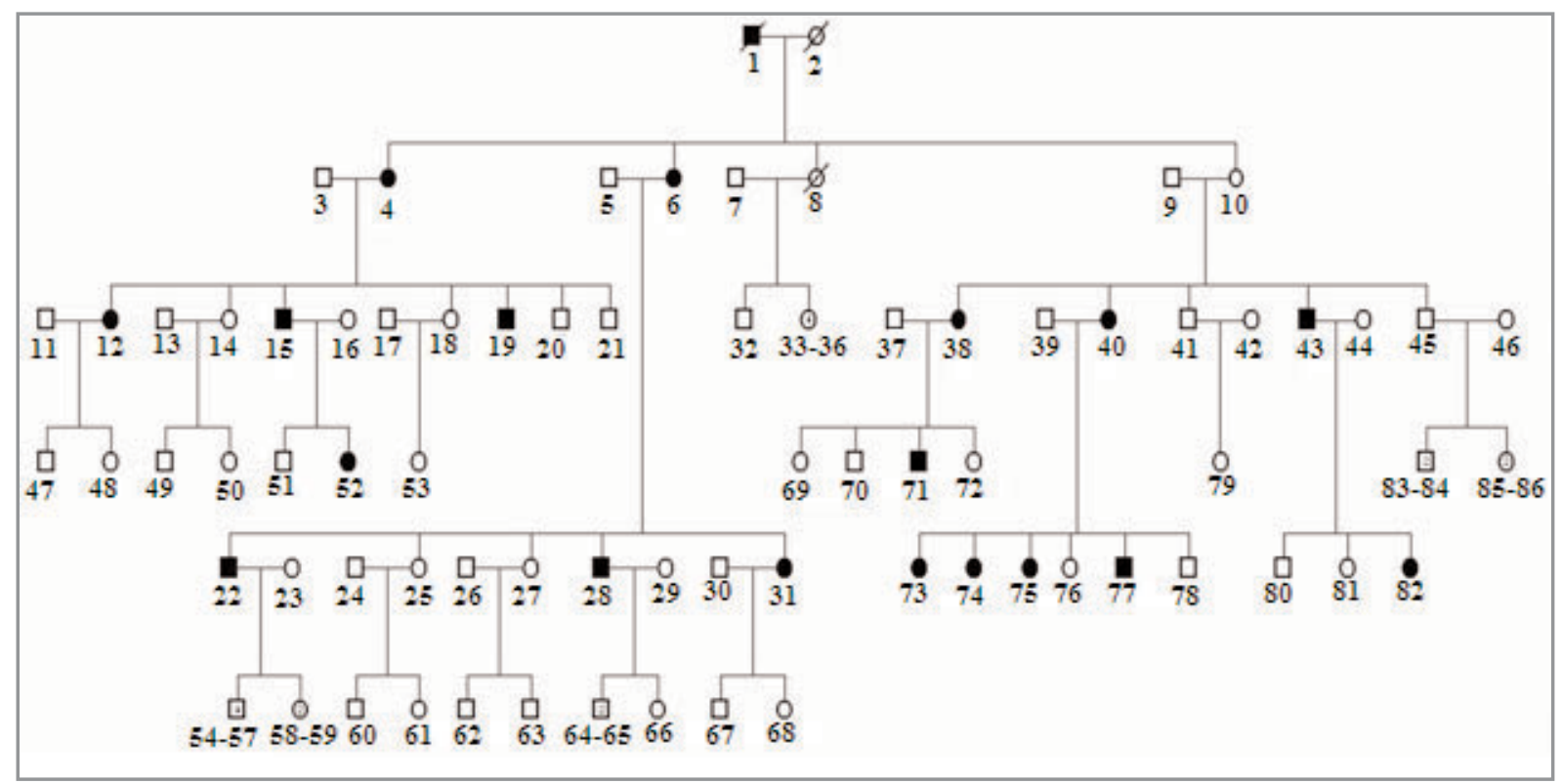

Figure 1. The pedigree of the four generation Hereditary Spherocytosis family. Proband is shown with an arrow. Affected individuals are shown with filled symbols and normals with clear symbols. There is a reduced penetrance in this family as seen in the pedigree in individual 10.

The linkage to the major genes in HS (SPTA1, SPTB, $A N K 1$ and $S L C 4 A 1)$ was searched using the linkage analysis. We analysed SPTA1 gene because $\alpha$-spectrin takes an important place in forming spectrin protein. ${ }^{19}$ In other words a defect in $\alpha$-spectrin affects spectrin formation. SPTA1 defect cause an autosomal recessive $\mathrm{HS}$ and moreover SPTAl gene defects are frequently seen in some populations. For these reasons we included the SPTAl gene in our study. We excluded the protein 4.2 coding $E P B 42$ gene because a defect in this gene was identified in an autosomal recessive HS and notable especially in Japanese population..$^{21}$

Peripheral venous blood was obtained from 24 individuals of the family and genomic DNA was extracted from peripheral blood lymphocytes according to standard procedures. We used polymorphic DNA markers selected from the http://research.marshfieldclinic.org and http://www.ensembl.org internet sites as seen in Table 1. We used polymorphic microsatellite markers for SPTA1: D1S1653 and D1S2635; for $S P T B$ D14S1012, D14S1046, D14S1069; for ANK1: D8S1051,D8S268 and for SLC4A1 D17S932, D17S1861, D17S1325, D14S1299, D14S951.
PCR amplification, 7\% denaturant polyacrylamide gel electrophoresis, and silver staining methods were used to separate the alleles. Gels were manually photographed for genotyping. Haplotypes were constructed using the program CYRILLIC 2.1. Allele sizes for each particular marker were sized using pBRHaeIII DNA ladder. In figure 2; there is a denaturant polyacrylamide gel photo of chromosome 14 .

Two-point linkage analysis was performed by using the MLINK program of the FASTLINK implementation of the LINKAGE program package. ${ }^{22,23,24} \mathrm{An}$ autosomal dominant model with a penetrance of 0.85 was assumed. Mutant allele frequencies were kept as 0.0001 and normal allele frequencies were 0.9999 . There was a reduced penetrance in this family as seen in the pedigree in individual 10.

The parametric component of the MERLIN package v1.01 was used for the multipoint analysis..$^{25,26}$ In the map file of MERLIN program, genetic positions (cM) of the DNA markers were provided from the internet site of Marshfield Clinic Research Foundation (http://research.marshfieldclinic.org/ genetics/ Genetic Research/ data/maps). 
Table 1. The polymorphic markers and their sequences that used in amplification of ANK1, SPTB, SPTA1, SLC4A1 genes.

\begin{tabular}{|c|c|c|c|}
\hline Gene & Chromosome location & Genetic Marker & Genetic marker sequence \\
\hline \multirow[t]{4}{*}{ ANK1 } & $8 p 11.2$ & D8S1051 & F: CTGCATTACAGCCTGGATG \\
\hline & & & R: AAGAGTAGATGGGAGGCAA \\
\hline & & D8S268 & F: ACCTACAAGCAACAACACCA \\
\hline & & & R: GTTGACTTCCATGGCTCTIT \\
\hline \multirow[t]{6}{*}{ SPTB } & $14 q 23-q 24.1$ & D14S1012 & F:GGCATCAGGGCAATGT \\
\hline & & & R:CACCAGTTGGGAATGAGA \\
\hline & & D14S1046 & F:CATTGGAGTTGAGTGGTTGA \\
\hline & & & R:СCTCTGTGGATTCTGGGA \\
\hline & & D14S1069 & F:TGTTCTAGTTGATGTGAGACTT \\
\hline & & & R:TATTTGAGGACCTGCTGTAA \\
\hline \multirow[t]{10}{*}{ SLC4A1 } & $17 q 21-q 22$ & D17S932 & F: GCTAAAAATACACGGATGG \\
\hline & & & R: TGCAAGACTGCGTCTC \\
\hline & & D17S1861 & F: AGGGGCAGCAGTCCTGTA \\
\hline & & & R:ACATCATCCTGAAATCTAATGG \\
\hline & & D17S1325 & F:AAAGGTGGCAATTCACAGTTG \\
\hline & & & R:GTGATAAAACTCAGTGGTACC \\
\hline & & D17S1299 & F:TAGCACTTGAGCACACATGG \\
\hline & & & R: GTGCATTATGGGGACCATTA \\
\hline & & D17S951 & F: GGCCTCCCAAACTGCTT \\
\hline & & & R: TCTACCCCGATGAGCCA \\
\hline \multirow[t]{4}{*}{ SPTA1 } & 1q22-q23 & D1S1653 & F:GGAAAGCCTGTAGGAAGAGG \\
\hline & & & R: CCTGGATGACAGAGTGCTCT \\
\hline & & D1S2635 & F: TAGCAGATCCCCCGTC \\
\hline & & & R:TGAATCCTACCCCTAAGTAAT \\
\hline
\end{tabular}

\section{RESULTS}

We studied with 24 members of autosomal dominant HS family. After the linkage analysis, the maximum LOD-score, $\mathrm{Zmax}=4.628$ at recombination fraction $\theta=0,00$ was obtained for the SPTB gene with markers D14S1012, D14S1046, D14S1069 and under $85 \%$ penetrance. The other LOD-scores for ANK1, SPTAI and SLC4Al genes were negative as seen in Table 2. Haplotype analysis of chromosome 14 is given in Figure 3. We detected two recombination events in unaffected individuals 69 and 72 positioned to the distal site of the SPTB gene.

By using multipoint analysis (MERLIN) we obtained the maximum LOD-score, $\mathrm{Zmax}=3.775$. In haplotype analysis we observed the segregation between disease allele and the genetic markers specific for regi- on $14 q 23-q 24$. The multipoint analysis graphic of two genetic markers used for the chromosome 14 is shown in Figure 4.

Eventually; by using LINKAGE and MERLIN analysis and LOD-score statistical calculations, we determined that there was an autosomal dominant form of HS in this family which is linked to the $S P T B$ gene which maps to chromosome 14. Although combined spectrin-ankyrin defect was the most common abnormality in this disease ${ }^{18,19}$, this hypothesis is excluded for this family because no linkage was found in ankyrin gene localization. Linkage analysis was shown to be an effective pre-screening method in genetically heterogeneous diseases. A new mutation analysis study is in the planning stage to detect the mutation in the SPTB gene. 


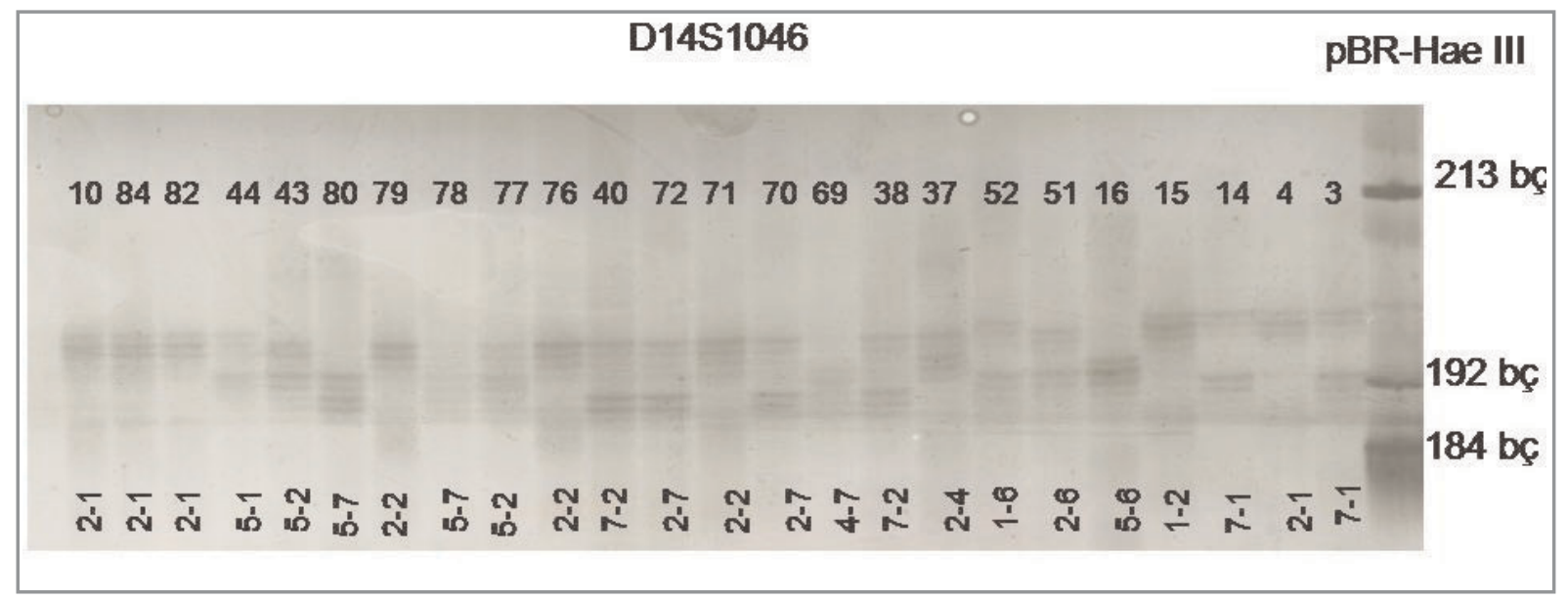

Figure 2. Denaturant polyacrylamide gel photo of chromosome 14 .

\section{DISCUSSION}

The basic pathological defect in HS lies in the membrane of the red cell. Main features of the genes encoding the red cell membrane proteins are given in Table 3. Intensity of HS is stated as mild, moderate, moderately severe, and severe according to some clinical laboratory variables which are hemoglobin and bilirubin concentrations, and reticulocyte count. ${ }^{6}$ All of these clinical and genetic features are summarized in Table 4.
We studied a large family of four generations in Turkish population with autosomal dominant HS and isolated spectrin deficiency. Linkage analysis using microsatellite markers showed evidence for linkage between HS and the $\beta$-spectrin gene. We examined markers D14S1012, D14S1046 and D14S1069 and showed co-segregation with HS.

According to clinical prospect, biochemical phenotype and molecular deficiencies; HS is a heterogeneous disorder. ${ }^{27}$ In Northern European populations with HS, ankryrin deficiency is the most common bioche-

\begin{tabular}{|c|c|c|c|c|c|}
\hline \multirow[t]{2}{*}{ Chromosome } & \multirow[t]{2}{*}{ Genetic Marker } & \multicolumn{4}{|c|}{ Recombination Fraction $(\theta=\mathrm{cM})$} \\
\hline & & 0.00 & 0.05 & 0.10 & 0.20 \\
\hline \multirow[t]{2}{*}{1} & D1S1653 & -3.334 & -0.439 & -0.232 & -0.084 \\
\hline & D1S2635 & -3.963 & -0.857 & -0.500 & -0.181 \\
\hline 8 & D8S1051 & $-\infty$ & -2.146 & -1.241 & -0.429 \\
\hline \multirow[t]{6}{*}{17} & D17S1299 & $-\infty$ & 1.129 & 1.405 & 1.323 \\
\hline & D17S932 & $-\infty$ & 0.741 & 1.095 & 1.133 \\
\hline & D17S1325 & $-\infty$ & 0.932 & 1.226 & 1.179 \\
\hline & D17S951 & $-\infty$ & -0.360 & 0.055 & 0.272 \\
\hline & D17S1861 & $-\infty$ & 0.917 & 1.009 & 0.875 \\
\hline & D17S2180 & 0.745 & 0.672 & 0.598 & 0.448 \\
\hline \multirow[t]{3}{*}{14} & D14S1012 & 1.659 & 1.483 & 1.302 & 0.93 \\
\hline & D14S1046 & 4.628 & 4.236 & 3.828 & 2.954 \\
\hline & D14S1069 & 2.694 & 2.556 & 2.363 & 1.861 \\
\hline
\end{tabular}




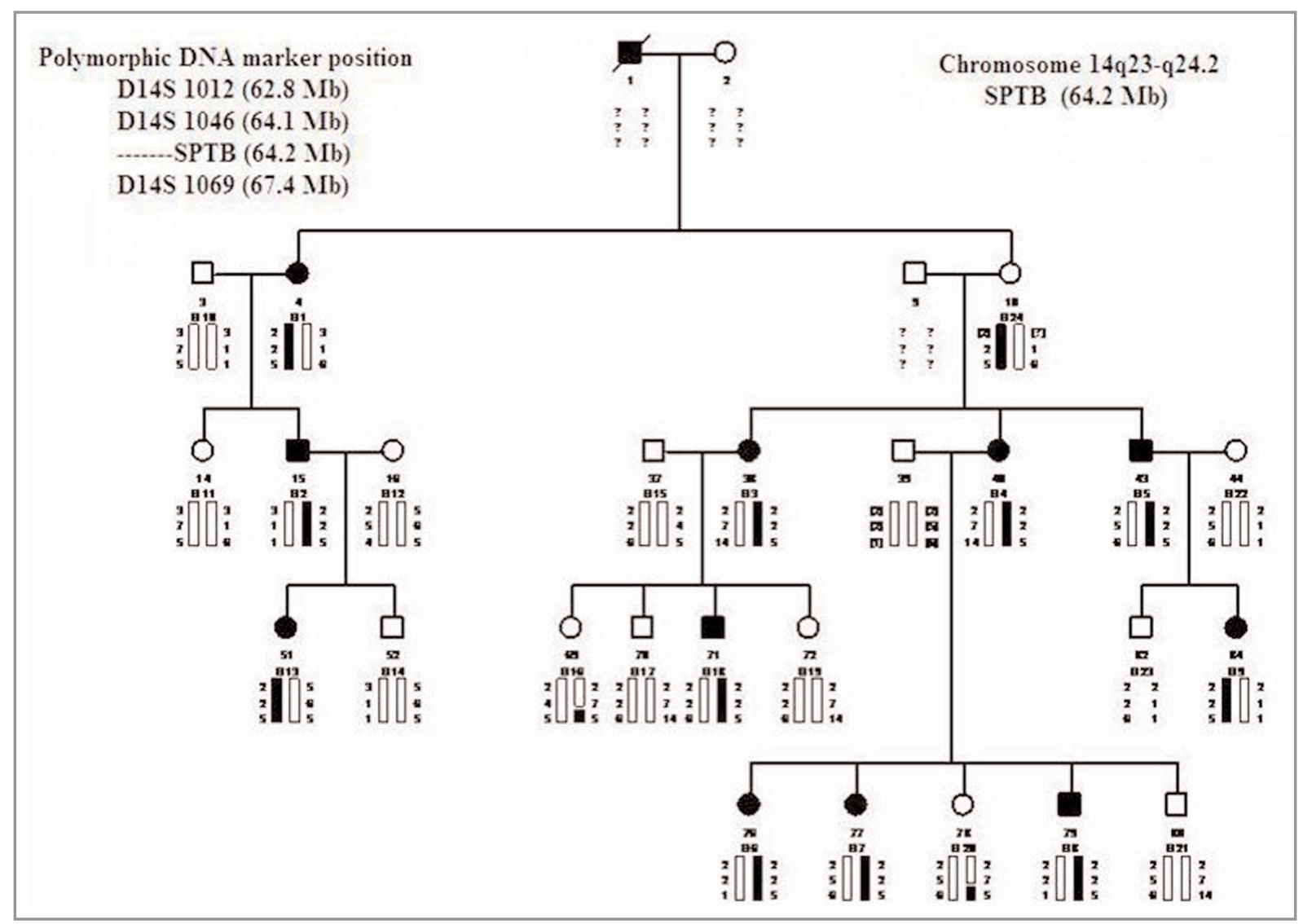

Figure 3. Haplotype analysis of chromosome 14. Individuals used in the linkage analysis are numbered 1-84. The order and the physical locations $(\mathrm{Mb})$ of the DNA markers are shown to the upper left. Two recombination events in unaffected individuals 69 and 78 placed the disease locus distal to the disease gene SPTB (64.2 Mb).

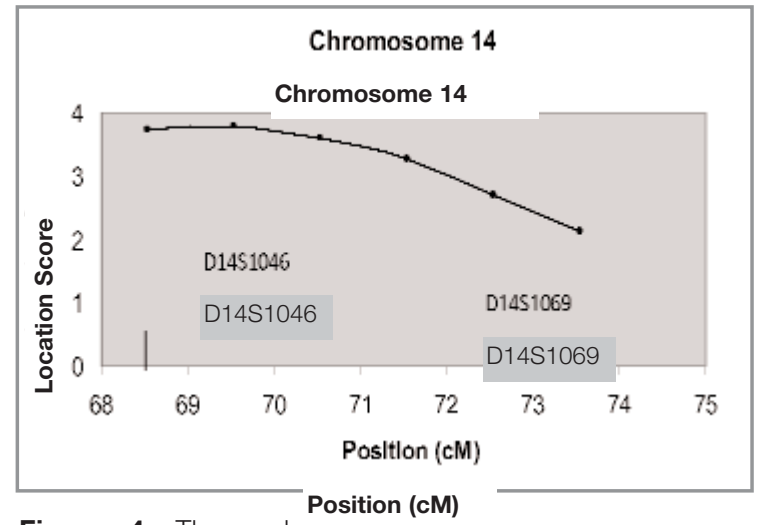

Figure 4. The mul-

tipoint analysis graphic of two genetic markers used for the chromosome 14. mical abnormality in approximately $50-60 \%$ of cases. ${ }^{5.28}$ Ankyrin mutations lead to both autosomal dominant and recessive HS and clinical severity of HS changes from mild to severe. Ankyrin binds both spectrin and band 3, so ankyrin deficiency can cause a functional decrease in spectrin and band 3 proteins on the RBC membrane. ${ }^{10}$ Combined ankyrin and spectrin deficiency was detected in most cases of HS. In these cases the ankyrin defect was the primary molecular defect and spectrin deficiency was secondary to the loss of ankyrin binding region. ${ }^{17,18}$ Isolated spectrin deficiency constitutes $20 \%$ of HS cases and clinical severity of HS changes from mild to moderately severe in patients with $\beta$-spectrin while an $\alpha$ spectrin defect causes severe HS. Miraglia et al reported that isolated spectrin deficiency was the most common abnormality among Italian HS patients. ${ }^{29}$ Band 3 deficiency is found in approximately $15-20 \%$ of HS patients and cause mild to moderate clinical view. ${ }^{30,31}$ 
Table 3. Main features of the genes encoding the red cell membrane proteins.

\begin{tabular}{|llll|}
\hline Protein & Gene & Location & Inheritance \\
\hline$\alpha$ - Spectrin & SPTA1 & $1 \mathrm{q} 22-\mathrm{q} 23$ & Recessive \\
$\beta$ - Spectrin & SPTB & $14 q 23-q 24.2$ & Dominant \\
Ankyrin & ANK1 & $8 p 11.2$ & Dominant \\
Band 3 & SLC4A1 & $17 q 12-q 21$ & Dominant \\
Protein 4.2 & EPB42 & $15 q 15-q 21$ & Recessive \\
\hline
\end{tabular}

The incidence and prevalence for HS have not been clearly established in Turkey but there are some reports for Italy and Greece. ${ }^{29,32}$ We share a common Mediterranean geography with these populations. Other deficiencies previously have been reported for some populations but spectrin deficiency is the most common HS defect for the Mediterranean ancestry. ${ }^{33}$

In previous studies, RBC membrane protein quantitative analysis by gel electrophoresis (SDS-PAGE analysis) or direct DNA sequence analysis were performed by the other researchers. In our study, we decided perform linkage analysis because our family was appropriate for this study as the family was large with four generations. Linkage analysis is a rapid and effective pre-screening method in genetically he- terogeneous diseases if the size of the physical construction of the gene is considered. In the literature we see that linkage analysis is used in large families but there are few studies made with this method for HS families. For example Garbarz et al in 1998 studied a three generation autosomal dominant HS family and searched for linkage between dominant HS and SPTB and ANK1 genes and linkage was shown between autosomal dominant HS and the SPTB gene. ${ }^{1}$

LODscore was calculated as 3,6 for the polymorphic genetic markers D14S63 and D14S271. We used different polymorphic markers for the SPTB gene such as D14S1012, D14S1046 and D14S1069 and we found the same result.

Table 4. Clinical and genetic features of HS (AD; Autosomal dominant, AR; autosomal recessive, Sp; spectrin, Ank; ankyrin, pro 4.2; protein 4.2, SDS-PAGE; sodium dodecyl sulphate polyacrylamide gel electrophoresis [10].

\begin{tabular}{|lllll|}
\hline & Mild & Moderate & Moderately Severe & Severe \\
\hline Haemoglobin (g/L) & Normal & $>80$ & $60-80$ & $<60$ \\
Reticulocytes & $<6 \%$ & $>6 \%$ & $>10 \%$ & $>10 \%$ \\
Bilirubin( $(\mu \mathrm{mol} / \mathrm{L})$ & $>34$ & $34-51$ & $>51$ \\
Peripheral smear & $17-34$ & spherocytes & spherocytes & Microspherocytes \\
& Some spherocytes & & & and poikilocytosis \\
Splenectomy & Rarely & in some cases & Necessary & Necessary \\
& & & (at $>5$ years) & (at $>2-3$ years) \\
SDS-PAGE & Normal & Sp,Ank+Sp, & Sp,Ank+Sp, & Sp,Ank+Sp, \\
(protein deficiency) & band3, pro 4.2 & band3 & band3 \\
Heredity & AD, de novo mut. & AD, de novo mut. & AR \\
\hline
\end{tabular}


Reduced penetrance observed in our family in individual 10 is a feature of autosomal dominant inheritance. The term 'reduced penetrance' means that some subjects with the genotype may not express the phenotype. The individual 10 had an affected father, two affected sisters and three affected children but she had no HS phenotype. The penetrance proportion is 0,85 . In HS, reduced penetrance was not mentioned before in the literature.

As a result, in genetically heterogeneous diseases like HS, there is not a practical way to find the responsible gene by analysing the phenotype. The biochemical defect is not directly reflective of the molecular defects. For example, mutations of spectrin or ankyrin genes can cause a decrease in spectrin assembly on the RBC membrane..$^{10}$ After a large family carrying HS is detected, linkage analysis is the best pre-screening method to initially diagnose the molecular defect. DNA sequence analysis is the following step to detect the mutation in the defined gene. We showed the linkage between HS and $\beta$ - spectrin gene. A new mutation analysis study is in the planning stage to detect the mutation in the SPTB gene.

\section{ACKNOWLEDGMENTS}

This study was supported by The Selcuk University Scientific Resarch Foundation (number 06102006). We thank the family and the referring physicians of the patient for their cooperation. We thank to Nurten Akarsu M.D. for her great support.

\section{REFERENCES}

1. Garbarz M, Galand C, Bibas D, et al, A 5' splice region $\mathrm{G} \rightarrow \mathrm{C}$ mutation in exon 3 of the human $B$ spectrin gene leads to decreased levels of $B$ spectrin mRNA and is responsible for dominant hereditary spherocytosis (Spectrin Guemere- Penfao). Br J Haematol 100: 90-98, 1998.

2. Becker PS, Tse WT, Lux SE, Forget BG. B spectrin kissimmee: A spectrin variant associated with autosomal dominant hereditary spherocytosis and defective binding to protein 4.1. J Clin Invest 92: 612-616, 1993.

3. Whitfield CF, Follweiler JB, Lopresti-Morrow L, Miller BA. Deficiency of a-spectrin synthesis in burst-forming units-erythroid in lethal hereditary spherocytosis. Blood 78: 3043- 3051, 1991.

4. Tse WT, Lux SE. Red blood cell membrane disorders. Br J Haematol 104: 2-13, 1999.
5. Eber SW, Gonzales JM, Lux ML, et al, Ankryrin-1 mutations are a major cause of dominantand recessive hereditary spherocytosis. Nature Genetics 13: 214218, 1996.

6. Wichterle H, Hanspal M, Palek J, Jarolim P. Combination of two mutant alpha spectrin alleles underlies a severe spherocytic hemolytic anemia. J Clin Invest 98: 2300-2307, 1996.

7. Mariani M, Barcellini W, Vercellati C, et al, Clinical and hematologic features of 300 patients affected by hereditary spherocytosis grouped according to the type of the membrane protein defect. Haematologica 93: 1310-1317, 2008.

8. Perrotta S, Gallagher PG, Mohandas N. Hereditary spherocytosis. Lancet 372: 1411-1426, 2008.

9. Gallagher PG, Forget BG. Hematologically important mutations: Spectrin and ankyrin variants in hereditary spherocytosis. Blood Cells, Molecules, and Diseases 24: 539-543, 1998.

10. Iolascon A, Avvisati RA. Genotype/phenotype correlation in hereditary spherocytosis, Haematologica 93: 1283-1288, 2008.

11. Maillet P, Alloisio N, Morlè L, Delaunay J. Spectrin mutation in hereditary elliptocytosis and hereditary spherocytosis. Hum Mutat 8: 97-100, 1996.

12. McMullin MF. The molecular basis of disorders of the red cell membrane. J Clin Pathol 52: 245-248, 1999.

13. Birkenmeier CS, Barker JE. Hereditary haemolytic anaemias: unexpected sequelae of mutations in the genes for erythroid membrane skeletal proteins. J Pathol 204: 450-459, 2004.

14. Hassoun H, Palek J. Hereditary spherocytosis: a review of the clinical and molecular aspects of the disease. Blood Rev 10:129-147, 1996.

15. Agre P, Caella JF, Zinkham WH, et al. Partial deficiency of eryhtrocyte spectrin in hereditary spherocytosis. Nature 314: 380-383, 1985.

16. Lux SE, John KM, Bennett $V$. Analysis of cDNA for human erythrocyte ankyrin indicates a repeated structure with homology to tissue-differentiation and cellcycle control proteins. Nature 344: 36-42, 1990.

17. Costa FF, Agre P, Watkins PCet al. Linkage of dominant hereditary spherocytosis to the gene for the erythrocyte membrane- skeleton protein ankyrin. N Engl J Med 323: 1046-1050, 1990.

18. Pekrun A, Eber SW, Kuhlmey A, Schroter W. Combined spectrin and ankyrin deficiency in hereditary spherocytosis. Ann Hematol 67: 89-93, 1993.

19. Savvides P, Shalev O, John KM, Lux SE. Combined spectrin and ankyrin deficiency is common in autosomal dominant hereditary spherocytosis. Blood 82: 2953-2960, 1993.

20. Eber S, Lux SE. Hereditary spherocytosis-defects in proteins that connect the membrane skeleton to the lipid bilayer. Seminars in Hematology 41: 118-141, 2004. 
21. Yawata Y, Kanzaki A, Yawata A, et al. Characteristic features of the genotype and phenotype of hereditary spherocytosis in the Japanese population. Int J Hematol 71: 118-135, 2000.

22. Lathrop GM, Lalouel JM, Julier C, Ott J. Strategies for multilocus linkage analysis in humans. Proc Natl Acad Sci 81: 3443-3446, 1984.

23. Cottingham RWJ, Idury RM, Schaffer AA. Faster sequential genetic linkage computations. Am J Hum Genet 53: 252-263, 1993.

24. Schaffer AA, Gupta SK, Shriram K, Cottingham RWJr. Avoiding recomputation in linkage analysis. Hum Hered 44: 225-237, 1994.

25. Abecasis GR, Cherny SS, Cookson WO, Cardon LR. Merlin rapid analysis of dense genetic maps using sparse gene flow trees. Nat Genet 30, 97-101, 2002.

26. Abecasis GR, Wigginton JE. Handling marker-marker linkage disequilibrium: pedigree analysis with clustered markers. Am J Hum Genet 77: 754-767, 2005.

27. Palek J, Jarolim P. Clinical expression and laboratory detection of red cell membrane protein mutations. Semin Hematol 30: 249-83, 1993.

28. Lanciotti M, Perutelli P, Valetto A, et al. Ankyrin deficiency is the most common defect in dominant and non dominant hereditary spherocytosis. Haematologica 82: 460-462, 1997.

29. Miraglia del Giudice E, Iolascon A, Pinto L, et al. Erythrocyte membrane protein alterations underlying clinical heterogeneity in hereditary spherocytosis. $\mathrm{Br} \mathrm{J}$ Haematol 88: 52-55, 1994.

30. Jarolim P, Murray JL, Rubin HL, et al. Characterization of 13 novel band 3 gene defects in hereditary spherocytosis with band 3 deficiency. Blood 88: 43664374, 1996.
31. Dhermy D, Galand C, Bournier O, et al. Heterogenous band 3 deficiency in hereditary spherocytosis related to band 3 deficiency. Br J Haematol 98: 32-40, 1997.

32. Premetis E, Stamoulakatou A, Loukopoulos D. Hereditary spherocytosis in Greece: collective data on a large number of patients. Hematology 4: 361-366, 1999.

33. Sanchez-Lopez JY, Camacho AL, Magana MT, et al. Red cell membrane protein deficiencies in Mexican patients with hereditary spherocytosis. Blood Cells Mol Dis 31: 357-359, 2003.

\section{Correspondence}

Dr. Pelin TAŞDEMIR

Selçuk Üniversitesi Meram Tıp Fakültesi

Kan Merkezi

42090 Meram, KONYA / TURKEY

Tel: (+90.332) 2236487

Fax: (+90.332) 2494220

e-mail: pelinvural@hotmail.com 
